\title{
Intention and Oral Health Behavior Perspective of Islamic Traditional Boarding School Students Based on Theory of Planned Behavior
}

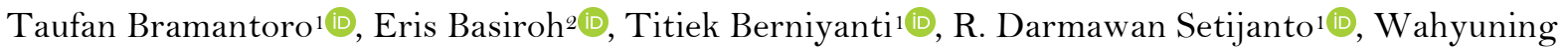 \\ Ratih Irmalia ${ }^{3}$ (1)
}

\begin{abstract}
${ }^{1}$ Department of Dental Public Health, Faculty of Dental Medicine, Universitas Airlangga, Surabaya, Indonesia.
${ }^{2}$ Faculty of Dental Medicine, Universitas Airlangga, Surabaya, Indonesia.

${ }^{3}$ Indonesian Health Collaboration and Innovation Institute, Surabaya, Indonesia.
\end{abstract}

Author to whom correspondence should be addressed: Taufan Bramantoro, Department of Dental Public Health, Faculty of Dental Medicine, Universitas Airlangga, Jalan Mayjend Prof. Dr. Moestopo no 47 Surabaya, Indonesia. Phone: +6231 5030255. E-mail: taufan-b@fkg.unair.ac.id.

Academic Editors: Alessandro Leite Cavalcanti and Wilton Wilney Nascimento Padilha

Received: 22 July 2019 / Accepted: 27 January 2020 / Published: 25 February 2020

How to cite this article: Bramantoro T, Basiroh E, Berniyanti T, Setijanto RD, Irmalia WR. Intention and oral health behavior perspective of Islamic traditional boarding school students based on theory of planned behavior. Pesqui Bras Odontopediatria Clín Integr. 2020; 20:e4977. https://doi.org/10.1590/pboci.2020.039

\begin{abstract}
Objective: To analyze the correlation of the students in an Islamic boarding school intention toward oral health behavior by means of the Theory of Planned Behavior (TPB) approach. Material and Methods: A cross-sectional analytic study was conducted on 153 students of an Islamic boarding school who fulfilled the criterion. Data were obtained by a questionnaire and clinical examination. Data were presented as mean and standard deviation. Results: The highest score of the variable that affects behavior recorded from both male and female respondents was Subjective Norm $(57.288 \pm 12.828)$, followed by Attitude (25.627 \pm 4.144$)$. Meanwhile, the lowest score that affects behavior was Oral Health Knowledge $(3.179 \pm 1.402)$. All study variables, according to the theory of planned behavior, such as knowledge, attitude, subjective norm, perceived behavior control, and intention had significant value to predict and assess behavior with $\mathrm{p}<0.05$. Conclusion: Attitude, subjective norms, perceived behavioral control, and oral health knowledge in Private Boarding School's Santris influence the intention to improve oral hygiene behavior.
\end{abstract}

Keywords: Oral Health; Health Behavior; Health Knowledge, Attitudes, Practice. 


\section{Introduction}

Islamic boarding school is an Islam-based educational institution with a boarding school system, where the students and teachers live in the same neighborhood, in a dormitory, and tend to be a closed community [1]. The number of Islamic boarding schools in Indonesia is about 27,230 with the majority located in Java Island $(78.6 \%)$ with the total number of the student as many as 3.8 million; therefore, Islamic boarding school attracts special concern in research [2,3]. This boarding system education functions as a method of intensive religion-related study, Islamic culture conservation, and also preparing promising Islamic scholars [4]. Aside from academic and religious studies, Islamic boarding schools also provide character education and hold proverb "purity is half of the iman (faith)" [5]. Therefore, maintaining personal hygiene, as a part of health behavior, is not only a habit but also a part of the faith itself. Islamic boarding schools are expected to be able to educate the students in all aspects in accordance with the values and norms of Islam, including aspects of oral health [6,7].

Based on our prior pilot study to 30 students at Al-Yasini Islamic boarding school, Pasuruan, East Java, it was found that the dental health status of students showed that from 30 students, 27 students had cavities with high DMF-T score of 4.6. The result denoted that about $90 \%$ of students had poor dental status. Another study also found that the healthy living behavior of children in Islamic Boarding School was poor. It was stated that the general health conditions, with reference to health care access, healthy behavior, and a healthy environment were unsatisfactory [8]. Despite its integrated and comprehensive system, the possible cause of these unsatisfactory findings regarding the student's oral health remains unknown. Considering the educational attempt, this current research aimed to analyze the role of students' intention in predicting dental and oral health maintaining behavior, based on the Theory of Planned Behavior (TPB).

Human behavior can be explained by various theories, one of which is the TPB. This theory is known as the socio-psychological model that is able to predict and assess human behavior. Based on the theory of planned behavior, there are subjective norms variable to predict the influence of the closest-related people in the environment against certain individual behavior [9]. The theory of planned behavior was developed in an attempt to predict human behavior. The TPB posits that attitude toward the behavior, subjective norm, and perceived behavioral control influence behavioral intention [10].

\section{Material and Methods}

\section{Study Design and Sample}

The respondents of this study were Al-Yasini Islamic boarding school students who had lived for at least one year, aged 12-16 years old. As many as 153 students were recruited by simple random sampling, consisting of 74 males and 79 females. All respondents came from the same race (100\% Javanese). Socioeconomically, the respondents belong to the middle class (taken from the data that $60.78 \%$ of respondents received pocket money less than IDR 500,000, which equivalent to 33 USD monthly).

\section{Instruments and Measures}

The required data were obtained by means of a questionnaire and clinical examination. The questionnaire has been tested the validity of the content. After being declared valid, the questionnaire could be used as a tool to measure attitude, subjective norms, perceived control behavior, intention, oral hygiene behavior, and oral health knowledge to the respondents. 
There were two types of questions in this questionnaire form, which were semi-open ended and closed-ended questions. The semi-open ended question was intended to obtain information about the respondent characteristics. Whereas, closed-ended questions (35 questions) were used to determine the application of the theory of planned behavior that underlies the behavior of boarding school students in maintaining oral health, namely knowledge, attitudes, subjective norms, perceived behavior control, intentions, and behavior of the respondents in maintaining oral and dental health. All variables were given a score. The higher the score will show a better outcome.

\section{Oral Hygiene Behavior}

The five questions aimed to assess the behavior of Islamic boarding school students in maintaining oral hygiene, such as the frequency and duration of tooth brushing, tooth brushing time, gargling after meals, and the use of a shared toothbrush. Each answer was given a score in the range of 0-5, and subsequently, summarized to get behavior score. The higher the score indicated better oral hygiene behavior.

\section{Intention}

The five questions aimed to evaluate the intention (INT) of Islamic boarding school students to behave, such as the intentions to brush tooth twice a day, the intention to brush tooth every morning after breakfast and the night before sleep, the intention to gargle after having meal, the intention to clean teeth using toothbrush and toothpaste, and the intention to not use shared toothbrush. Indicators for making questions on questionnaires based on basic dental and oral health behaviors according to the NSW Health Center for Oral Health Strategy [11]. The respondents were asked to score each item in the range of 1-6, indicating disagree to agree. The range of the total score of this variable was 1-30.

\section{Attitude}

To assess the students' attitude, respondents were given five questions about the attitude (ATT) toward behavior, such as brushing behavior, in terms of frequency, time, and duration shared toothbrush, and brushing tooth for 2-3 minutes. The respondents were required to give a score to each question, in the range of 1-6. The range of the total score of this variable was 5-30. The higher the score showed a better attitude.

\section{Subjective Norms}

The fifteen questions aimed to find out the influence of the surrounding people in boarding school, such as peers, teachers, and parents towards the students' behavior. Respondents were required to give score for each statement, such as "My friends advise me to gargle after meals", "My parents advised me to brush my teeth with toothpaste and toothbrush to clean my teeth and mouth", "Ustadz (male Islamic teacher) and ustadzah (female Islamic teacher) advise me not to share toothbrush with friends". Each question had a range of 1-6 scores. The range of the total score of this variable was 15-90. The higher the score showed the higher the influence of the people around to behave.

\section{Perceived Behavioral Control}

The five questions aimed to assess the ability of respondents to conduct certain behavior, such as brushing tooth twice a day, brushing tooth after breakfast and night before sleep, brushing tooth using toothbrush and toothpaste, gargling after meals, and not sharing toothbrush between friends. The range score 
on each question was 1-6, from difficult to do until easy to do. The range of total scores in this variable was 530. So, the higher the score indicated that the respondent felt at ease to conduct the behavior. Therefore, it also indicated that they were certain of being able to perform such behavior.

\section{Oral Health Knowledge}

The five questions aimed to observe the knowledge of the respondents. The questions were adapted from previous research [12]. Questions on this variable included "Does caries affect the aesthetic of a person's oral cavity?", "Does sweet food affect dental and oral health?", "Can soft drinks affect oral health?", "Can oral health affect general health?”, “Are dental and oral diseases treatment as important as other organs treatment?". The total number of scores on this variable was $0-5$. The higher the score showed the higher the level of knowledge of the respondents.

\section{Statistical Analysis}

The acquired data were tabulated and presented as mean and standard deviation. A multivariate analysis was done using linear regression.

Ethical Aspects

This study was conducted in accordance with the approval of the Faculty of Dental Medicine Ethical Committee, with certificate number of 089/HRECC.FODM/VII.2017. All the respondents in this study have signed the informed consent represented by the teachers as guardians at the Islamic Boarding School, based on the parent's approval, in accordance with the provisions of informed consent by the Ethics Commission.

\section{Results}

Characteristics of respondents in this study consisted of gender, age, duration of stay in the boarding school, number of parent visits in 1 month, the amount of allowance per month, and madrasah school level in Islamic boarding schools. Table 1 describes the distribution of respondents based on these five characteristics.

Table 1. Distribution of demographic characteristics.

\begin{tabular}{lcc}
\hline \multicolumn{1}{c}{ Variables } & $\mathbf{N}$ & $\mathbf{\%}$ \\
\hline $\begin{array}{l}\text { Gender } \\
\quad \text { Male }\end{array}$ & 79 & 51.7 \\
$\quad$ Female & 74 & 48.3 \\
Age & & \\
$\quad<14$ Years & 31 & 20.3 \\
$\quad>14$ Years & 122 & 79.7 \\
Number of Parents Visit & & \\
$\quad<3$ Times & 97 & 63.4 \\
$\quad>3$ Times & 56 & 36.6 \\
Level of Education in Boarding School & & \\
$\quad$ Middle School & 82 & 53.6 \\
$\quad$ High School & 71 & 46.4 \\
Duration of Stay in Boarding School & & \\
$\quad<2$ Years & 102 & 66.7 \\
$\quad>2$ Years & 51 & 33.3 \\
Pocket Money per Month (Rupiah) & & \\
$\quad<500.000$ & 93 & 60.8 \\
$\quad>500.000$ & 60 & 39.2 \\
\hline
\end{tabular}


The result describes two findings: the descriptive explanation of factors influencing behavior based on the TPB, and the correlation of intention toward behavior. The questionnaire revealed that both male and female students scored approximately the same concerning oral hygiene behavior. Besides, the acquired data also determine the correlation between each variable in influencing behavior. In Table 2 , based on the questionnaire, the highest score of the variable that affects behavior recorded from both male and female respondents was Subjective Norm (57.288 \pm 12.828), followed by Attitude (25.627 \pm 4.144$)$. Meanwhile, the lowest score that affects behavior was Oral Health Knowledge $(3.179 \pm 1.402)$. Observing the result based on gender, both genders are showing the same manner. The obtained data from male respondents showed that variable with the highest score was Subjective norm (55.662 \pm 12.861$)$, followed by Attitude (24.405 \pm 4.354$)$, while the lowest score was Oral Health Knowledge (3.270 \pm 1.520$)$. As for the female, variable with the highest score recorded was SN $(58.923 \pm 12.732)$, followed by ATT $(26.795 \pm 3.619)$ and the lowest score was from Oral Health Knowledge $(4.154 \pm 1.140)$.

Table 2. Mean and standard deviation of variables that affect behavior according to theory of planned behavior.

\begin{tabular}{lcccccc}
\hline \multicolumn{1}{c}{ Variables (Range Score) } & \multicolumn{2}{c}{ Total } & \multicolumn{2}{c}{ Female } & \multicolumn{2}{c}{ Male } \\
& Mean & SD & Mean & SD & Mean & SD \\
\hline Attitude (5-30) & 25.627 & 4.144 & 26.795 & 3.619 & 24.405 & 4.354 \\
Subjective Norm (15-90) & 57.288 & 12.828 & 58.923 & 12.732 & 55.662 & 12.861 \\
Perceived Behavior Control (5-30) & 23.980 & 4.586 & 24.949 & 3.854 & 23.027 & 5.085 \\
Oral Health Knowledge (0-5) & 3.719 & 1.402 & 4.154 & 1.140 & 3.270 & 1.520 \\
Intention (5-30) & 24.163 & 5.107 & 25.872 & 3.760 & 22.446 & 5.725 \\
\hline
\end{tabular}

Based on Figure 1, it was found that Attitude variable had a significant relationship with intention with $\mathrm{p}<0.003$ and correlation coefficient $(\mathrm{r})$ of 0.503. It means that Attitude had a high significant correlation with intention. Then, the subjective norm had a significant relationship with intention with $\mathrm{p}<0.035$ and correlation coefficient (r) 0.367 , which means subjective norm had a less significant correlation with intention.

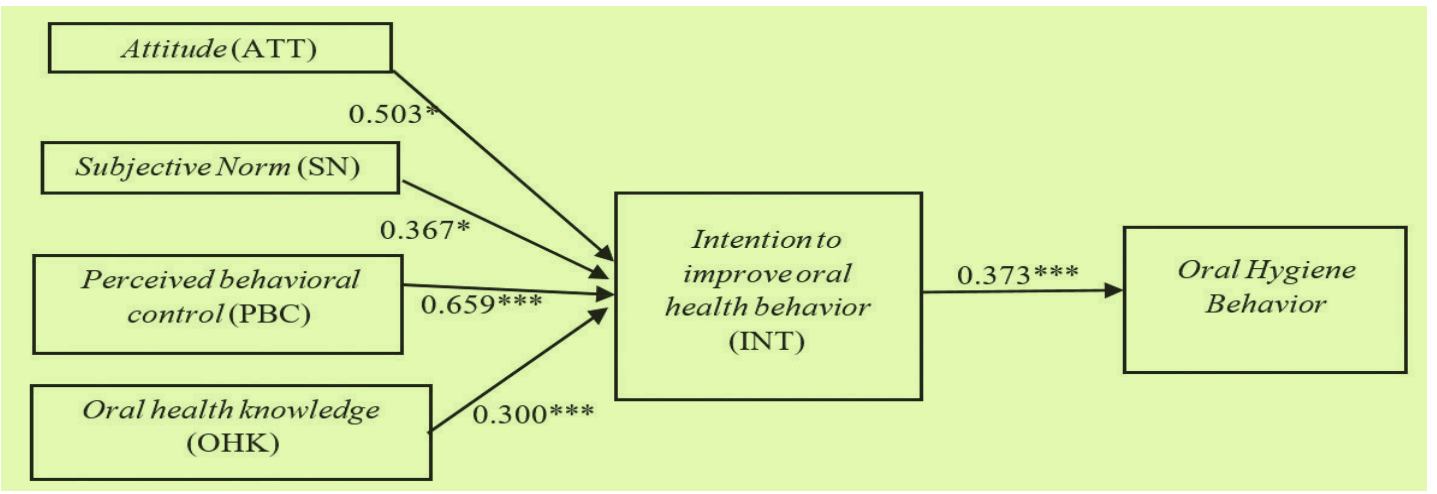

${ }^{*} \mathrm{p}<0.05 ; * * * \mathrm{p}<0.0001$

Figure 1. Regression test result.

Perceived behavioral control had a significant relationship with intention, with $\mathrm{p}<0.0001$ and correlation coefficient $(\mathrm{r})$ of 0.659. It means PBC had a high significant correlation with intention. In addition, Oral Health Knowledge had a significant relationship with intention, with $p<0.0001$ and correlation coefficient (r) of 0.300 , which means OHK had a less significant correlation with intention. Whereas, the intention had a significant relationship with $\mathrm{OHB}$ with $\mathrm{p}<0.0001$ and correlation coefficient $(\mathrm{r})$ of 0.373 . It means that the 
intention variable had a less significant correlation with OHB. However, the overall variable had a strong significance value, evidenced by the statistical test of $\mathrm{p}<0.05$ obtained. Table 3 explains the influence of variables toward the intention. Among variables, the ones with the strongest influence recorded were perceived behavioral control and Oral Health Knowledge $(\mathrm{p}<0.0001)$.

Table 3. Parameters model of intention.

\begin{tabular}{lcccc}
\hline \multicolumn{1}{c}{ Source } & Value & Standard Error & $\mathbf{t}$ & Pr $>|\mathbf{t}|$ \\
\hline Intercept & -0.846 & 1.996 & -0.424 & 0.672 \\
Attitude & 0.239 & 0.079 & 3.019 & 0.003 \\
Subjective Norm & 0.048 & 0.023 & 2.128 & 0.035 \\
Perceived Behavioral Control & 0.530 & 0.071 & 7.431 & $<0.0001$ \\
Oral Health Knowledge & 0.913 & 0.207 & 4.416 & $<0.0001$ \\
\hline
\end{tabular}

\section{Discussion}

This study found that the behavior of a student in Islamic Boarding School could be predicted by assessing intention through a theoretical approach, using TPB. We analyzed the students' behavior in maintaining dental and oral health. According to the result, the students' behavior in maintaining dental and oral health is acceptable. The theory of planned behavior defines that individuals' behavior is related to their intention, which also influenced by attitude, subjective norm, and perceived behavioral control. The statistical analysis showed that intention has a significant correlation to attitude, subjective norm, perceived behavioral control, and oral health knowledge $(\mathrm{p}<0.05)$.

In general, there are variables that may influence the intention, i.e., attitude, subjective norm, perceived behavioral control, and oral health knowledge, assessed with the goodness of fit statistics (R2) in which resulted in a score of 0.567 . It means that the aforementioned variables affect the intention as much as $56.7 \%$. These results are in accordance with previous studies, which stated that (27\%-52\%) attitude, subjective norm, perceived behavioral control, and oral health knowledge influence the intention to improve oral hygiene behavior [13-16]. The perceived behavioral control and oral health knowledge had the strongest influence on intention compared to the other variables. This is in line with previous research, which found that attitude, perceived behavioral control, and oral health knowledge can predict the intention to behave [16].

We found that attitude had a significant relationship with intention, which is in line with the previous study, which stated that there is a person's attitude toward behavior can affect one's intention to behave. The boarding school environment is an environment that has certain rules, certain facilities so that students of Islamic boarding school or boarding school feel to be able to perform oral hygiene behavior with maximum facilities, while the constraints to perform oral hygiene behavior is minimal. So, the higher the perceived behavioral control of a boarding school student, the higher the intention to do oral hygiene behavior [17].

The subjective norm variable had a significant relationship with intention $(\mathrm{p}<0.05)$. In the boarding school environment, teachers become role models that will be imitated by the students. If the influence of the surrounding environment is strong, then the subjective norm will be higher. This is in line with previous research [15].

The intention of santri to clean their teeth and mouth gets an average value for assessment. This is in line with the results of the average oral hygiene behavior, which is also acceptable. Generally, the result of this study is in line with previous research, which found that attitude, perceived behavioral control, and oral health knowledge can predict intention to behave [14]. This result signified an exquisite educational attempt from 
the boarding school, concerning the necessity of keeping dental and oral hygiene. However, unfortunately, the focal point of focusing solely on these observable, proximal behaviors. Therefore, it probably does not give the full picture of human behavior [18]. Further studies on human behavior or other aspects in the boarding school system, teenage psychological development is required to explain the poor dental health in spite of the good oral hygiene maintaining behavior.

The boarding school environment educates students in all aspects in accordance with Islamic religious values and norms, including aspects of oral health. In the boarding school environment, the role of the teacher is very large as a student role model for Islamic boarding schools. The norms that apply to the boarding school environment are adherence and a high level of trust from students to the boarding school teachers [15]. Overall components of the theory of planned behavior can predict the Islamic boarding school students' intentions to conduct oral health behavior. This result is consistent with the results of previous studies $[1,16,17]$.

\section{Conclusion}

Attitude, subjective norms, perceived behavioral control, and oral health knowledge in Private Boarding School's Santris influence the intention to improve oral hygiene behavior. Moreover, in a closed environment that is limited by rules, norms, and human interactions.

\section{Authors' Contributions}

\begin{tabular}{|c|c|c|}
\hline TB & (iD) $0000-0003-4123-333 \mathrm{X}$ & $\begin{array}{l}\text { Conceptualization, Methodology, Supervision, Data Curation, Writing-Review and } \\
\text { Editing, and Project Administration. }\end{array}$ \\
\hline $\mathrm{EB}$ & (iD) $0000-0002-4073-8590$ & Investigation, Resources, Data Curation, and Writing - Original Draft Preparation. \\
\hline $\mathrm{TB}$ & (iD) $0000-0002-2183-1140$ & $\begin{array}{l}\text { Conceptualization, Validation, Formal Analysis, Data Curation, and Writing - } \\
\text { Review and Editing. }\end{array}$ \\
\hline RDS & (iD) $0000-0001-7182-2712$ & Methodology, Validation, Data Curation, and Writing - Review and Editing. \\
\hline WRI & (iD) $0000-0001-5575-0552$ & $\begin{array}{l}\text { Writing - Original Draft Preparation, Writing - Review and Editing, and } \\
\text { Visualization. }\end{array}$ \\
\hline
\end{tabular}

\section{Financial Support}

None.

\section{Conflict of Interest}

The authors declare no conflicts of interest.

\section{References}

[1] Sari MME. The role of learning management of Islamic boarding school (Pesantren) in improvement of their students religious tolerance in West Java - Indonesia. Int J Innov Appl Stud 2017; 19(1):24-32.

[2] Departemen Agama RI. Daftar Jumlah Santri dan Nama Kyai Tahun 2008/2009. Available from: http://pendis.kemenag.go.id/file/dokumen/santri-kyai-pontren-81-82-91-92.pdf. [Accessed on June 14, 2019]. [In Indonesian]

[3] Departemen Agama RI. Analisis dan Interpretasi Data pada Pondok Pesantren, Madrasah Diniyah (Madin), Taman Pendidikan Quran (TPQ) Tahun Pelajaran 2011-2012. Available http://pendis.kemenag.go.id/file/dokumen/pontrenanalisis.pdf. [Accessed Sep 10, 2018]. [In Indonesian]

[4] Zakaria GAN. Pondok pesantren: changes and its future pondok pesantren. J Islam Arab Educ 2010; 2(2):45-52.

[5] Baharun H. Total moral quality: a new approach for character education in Pesantren. Ulumuna 2017; 21(1):57-80. https://doi.org/10.20414/ujis.v21i1.1167 
[6] Budiarti R. Tingkat keimanan Islam dan status karies gigi santri. J Heal Qual 2014; 5(1):1-8.

[7] Bramantoro T, Karimah N, Sosiawan A, Setijanto RD, Berniyanti T, Palupi R, et al. Miswak users' behavior model based on the theory of planned behavior in the country with the largest Muslim population. Clin Cosmet Investig Dent 2018; 10:141-8. https://doi.org/10.2147/CCIDE.S164403

[8] Susanto T, Sulistyorini L, Wuryaningsih EW, Bahtiar S. School health promotion: a cross-sectional study on Clean and Healthy Living Program Behavior (CHLB) among Islamic boarding schools in Indonesia. Int J Nurs Sci 2016; 3(3):291-8. https://doi.org/10.1016/j.ijnss.2016.08.007

[9] Ab Malik N, Mohamad Yatim S, Lam OLT, Jin L, McGrath C. Factors influencing the provision of oral hygiene care following stroke: an application of the theory of planned behaviour. Disabil Rehabil 2018; 40(8):889-93. https://doi.org/10.1080/09638288.2016.1277397

[10] Al-Omiri MK, Al-Wahadni AM, Saeed KN. Oral health attitudes, knowledge, and behavior among school children in North Jordan. J Dent Educ 2006; 70(2):179-87.

[11] Armitage CJ, Conner M. Efficacy of the theory of planned behaviour: a meta-analytic review. Br J Soc Psychol 2001; 4O(Pt 4):47 1-99. https://doi.org/10.1348/014466601164939

[12] Wang L, Wang L. Using theory of planned behavior to predict the physical activity of children: probing gender differences. Biomed Res Int 2015; 2015:1-9. https://doi.org/10.1155/2015/536904

[13] Buunk-Werkhoven YAB, Dijkstra A, van der Schans CP. Determinants of oral hygiene behavior: a study based on the theory of planned behavior. Community Dent Oral Epidemiol 2011 ; 39(3):250-9. https://doi.org/10.1111/j.1600-0528.2010.00589.x

[14] Dumitrescu AL, Wagle M, Dogaru BC, Manolescu B. Modeling the theory of planned behavior for intention to improve oral health behaviors: the impact of attitudes, knowledge, and current behavior. J Oral Sci 2011; 53(3):36977. https://doi.org/10.2334/josnusd.53.369

[15] Ajzen I. The theory of planned behavior. Organ Behav Hum Decis Process 1991; 50(2):179-2 11.

[16] Rhodes R, Courneya K. Modelling the theory of planned behaviour and past behaviour. Psychol Health Med 2003; $8(1): 57-69$.

[17] Dumitrescu AL, Dogaru BC, Duta C, Manolescu BN. Testing five social-cognitive models to explain predictors of personal oral health behaviours and intention to improve them. Oral Health Prev Dent 2014; 12(4):345-55. https://doi.org/10.3290/j.ohpd.a31662

[18] Spruijt-Metz D, Hekler E, Saranummi N, Intille S, Korhonen I, Nilsen W, et al. Building new computational models to support health behavior change and maintenance: new opportunities in behavioral research. Transl Behav Med 2015; 5(3):335-46. https://doi.org/10.1007/s13142-015-0324-1 